\title{
The Effects of Concept Mapping Instruction on Students' Attitudes, Motivations, and Self-Efficacy in Educational Technology Class
}

\author{
Budour Almisad \\ The Public Authority for Applied Education and Training (PAAET) \\ College of Basic Education \\ PAAET, Kuwait \\ E-mail: b.almisad@paaet.edu.kw
}

Received: March 21, 2019 Accepted: April 17, 2019 Published: April 30, 2019

doi:10.5296/ijld.v9i2.14529

URL: https://doi.org/10.5296/ijld.v9i2.14529

\begin{abstract}
The purpose of this study was to examine the effect of concept mapping instruction on students' attitudes, motivation, and sense of self-efficacy in relation to conducting an educational technology project. A questionnaire was used to collect data from 78 students who were enrolled in three sections of a "production of teaching material" course in a college of education at a university in Kuwait. A pre-test/post-test pre-experimental design was followed, and data was collected using two questionnaires, one before and one after the use of a concept mapping approach to instruction. The analysis of the pre-test/post-test scores showed that there were significant differences between the post-test and pre-test mean scores on the three scales examined: attitude, motivation, and sense of self-efficacy. The findings indicate that the concept mapping approach to instruction was an effective tool for improving students' attitudes, motivation, and sense of self-efficacy in relation to conducting an educational technology project.
\end{abstract}

Keywords: Concept map, attitude, motivation, self-efficacy, educational technology, kuwait

\section{Study Background}

Students in the college of education take courses that require them to undertake educational projects that involve designing and developing digital educational environments and materials. While teaching some of these courses, the researcher noticed that the students lacked enthusiasm and determination when designing and developing such projects. The students 
were used to traditional educational strategies that tended to be learner-centred. The use of traditional educational strategies is common in the Kuwaiti educational system (Al-Nakib, 2015). Therefore, the current study examined the effects of learner-centred strategies that teach learners how to learn (i.e., concept mapping) on Kuwaiti college of education students' attitudes, motivation, and sense of self-efficacy in relation to conducting educational technology projects. Students' attitudes, motivation, and sense of self-efficacy in relation to educational tasks are critical for their success in higher education (Mills, 1991; Busato, Prins, Elshout, \& Hamaker, 2000; McKenzie \& Schweitzer, 2001). Students' attitude, motivation, and sense of self-efficacy can be influenced by the teaching approach and the learning activities used (Bernaus \& Gardner, 2008; Cheung, 2015).

According to Pintoi \& Zeitz (2017), "Concept mapping is an active, creative, visual and spatial learning activity" (p.114). Concept mapping can be classified as a cognitive and metacognitive approach to learning that focus on making the students understand the educational topics (Chen, Liang, Lee, \& Liao, 2011). Concept mapping involves the use of graphical representations of information that depict concepts and the relationships between them. The concepts are designated by labels and enclosed by closed shapes (e.g., circles or rectangles). The associations between concepts are shown by connecting lines that link them together. Some forms of concept mapping include descriptions of the relationships between the concepts using words on the linking lines. Concept mapping involves the use of different forms of graphical representations of information. Concept mapping focuses on providing visual presentations of information. Research has found a high percentage of visual learners among university students (Clarke III, Flaherty, \& Yankey, 2006).

The positive effects of concept mapping on students' learning have been verified in studies in various fields. Some studies have reported positive effects of the use of concept mapping on students' attitudes and motivations for conducting computing projects. For instance, reference (Al-Dmour, Gasaymeh, Abuhelaleh, \& Almi'ani, 2017) examined the effect of the concept mapping approach on undergraduate information technology students' attitudes and motivations towards documenting a computing capstone project. The results showed that the use of concept mapping as a tool to support student learning had a positive influence on their attitudes and motivations The researchers found that the use of the concept mapping instructional approach to prepare students to conduct a computing project enhanced their communication of their ideas related to the project, helped them in understanding the structure of the project, and improved their motivation and attitudes towards conducting the project. Some research has focused on the effect of the concept mapping approach to teaching on students' attitudes toward learning specific topics in specific fields. For instance, reference (Luchembe, Chinyama, \& Jumbe, 2017) investigated the effect of using concept mapping on university students' attitudes and achievements when studying the topic of circular and rotational motion in physics. The results showed that the use of the concept mapping approach improved students' attitudes and achievements. The students believed that the concept mapping approach helped them to learn, and they reported that they would use the concept mapping approach to teaching in their future careers as physics teachers. In another study, reference (Khoshsima, Saed, \& Hakimzade, 2016) examined the effect of the concept mapping 
approach to teaching on university students' attitudes and achievements when learning English as a foreign language. The findings showed that the use of the concept mapping approach to instruction had a positive and significant effect on students' attitudes towards vocabulary learning. In addition, the concept mapping approach improved students' attitudes and their performance in vocabulary's retention and learning. Some other studies have reported positive associations between the use of concept mapping and students' critical thinking ability. For instance, reference (Chen et al., 2011) investigated the effect of the concept mapping learning approach on nursing undergraduate students' critical thinking ability. The results showed that the use of concept mapping to teach students improved their ability to think critically.

Some research has focused on the effect of using the concept mapping approach to instruction on students' interest and motivation toward learning. For instance, reference (Chiou, 2008) examined the effect of the concept mapping approach on university students' learning achievement and interests in an accounting course. The results showed that the use of the concept mapping approach to teaching had a positive effect on their interest in learning accounting. Concept mapping helped the students' ability to understand, combine and explain accounting concepts. Reference (Keraro et al., 2007) examined the effect on school students' motivation in a biology class of a type of concept mapping that involved cooperation among students. The results showed that the concept mapping approach to teaching had significant and positive effects on students' motivation for learning biology.

The relationship between the use of the concept mapping teaching approach and students' sense of self-efficacy has been examined in other research. For instance, Reference (Chularut, \& DeBacker, 2004) examined the effect of the use of concept mapping as a learning strategy on students' sense of self-efficacy when learning English as a second language. The results showed that the concept mapping approach had significant and positive effects on the students' sense of self-efficacy. In a more recent study, reference (Nobahar, Nemat Tabrizi, \& Shaghaghi, 2013) examined the influence of the use of concept mapping on students' performance and sense of self-efficacy when learning English as a foreign language. The findings showed that the concept mapping approach had a positive effect on students' sense of self-efficacy and English writing performance.

Previous studies have examined the effect of the concept mapping approach to instruction on students' learning in various ways and in different fields. Some of common variables that have been found to have significant associations with the use of the concept mapping approach to teaching include students' attitudes, motivation, sense of self-efficacy, and achievements. However, the concept mapping approach to teaching has commonly been used in science and language learning. Reviewing the previous research revealed a lack of research into the use of concept mapping strategies in educational technology courses and in developing educational technology-related projects.

There have been a limited number of studies that have examined students' reactions to the use of the concept mapping approach to teaching in Kuwaiti higher education. The stakeholders in the Kuwaiti higher education system encourage faculty members to adopt teaching methods that focus on student-centered learning. However, the use of new educational methods such as 


\section{Macrothink

concept mapping requires examining students' reactions to such methods. Understanding students' reactions and beliefs about the use of the concept mapping approach to teaching is an important success factor for such use. Therefore, the current study examined the effects of the concept mapping approach to instruction on Kuwaiti university students' attitudes, motivation, and sense of self-efficacy in relation to conducting an educational technology-related project.

\section{Method}

A quantitative approach was followed in which a one-group pre-test/post-test pre-experimental design was used. Data was collected over two rounds using questionnaires. The first round of data collection took place before the use of the concept mapping intervention. The first questionnaire collected data regarding Kuwaiti university students' demographic characteristics and their attitudes, motivations, and sense of self-efficacy in relation to conducting and documenting an educational technology-related project. After providing students with concept mapping instruction in relation to designing and developing an educational technology-related project over two class meetings, round two of the data collection took place. The second questionnaire collected data regarding students' attitudes, motivations, and sense of self-efficacy in relation to conducting an educational technology-related project. (Figure. 1).

\begin{tabular}{cccc}
\hline Group & Pre-test & Independent Variable & Post-test \\
\hline E & Y1 & $\mathrm{X}$ & $\mathrm{Y} 2$ \\
\hline
\end{tabular}

Figure 1. Pre-Experimental Design, p.304 (Ary, Jacobs, Sorensen, \& Razavieh, 2010)

\subsection{Study Settings and Procedure}

The study took place in a "production of teaching materials" course. The course was designed to provide students with hands-on experience in how to design and develop educational environments and materials. Part of course required the students to complete an educational technology-related project that involved the design and development of technology-based educational environments and materials. Figure 2 shows aspects of the educational technology project. 


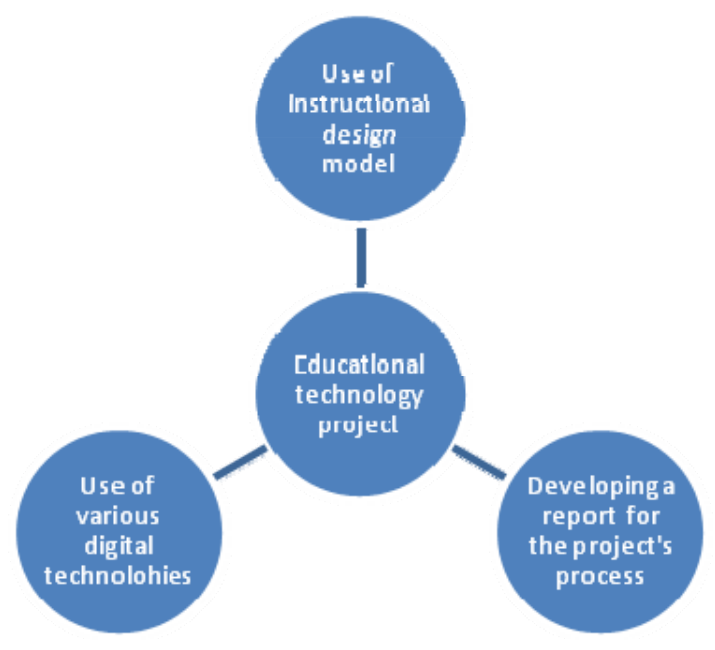

Figure 2. The educational technology project

The study involved collecting data regarding students' attitudes, motivations, and sense of self-efficacy in relation to conducting an educational technology-related project before and after the use of the concept mapping approach to instruction. Before the first round of data collection, the instructor provided a brief instruction about the project. Data collection process took place in the class using a paper-based questionnaire. Figure 3 shows the data collection procedure.

The questionnaire instrument was adminisered to measure students' attitudes, motivations, and sense of self-efficacy in relation to conducting an educational technology-related project.

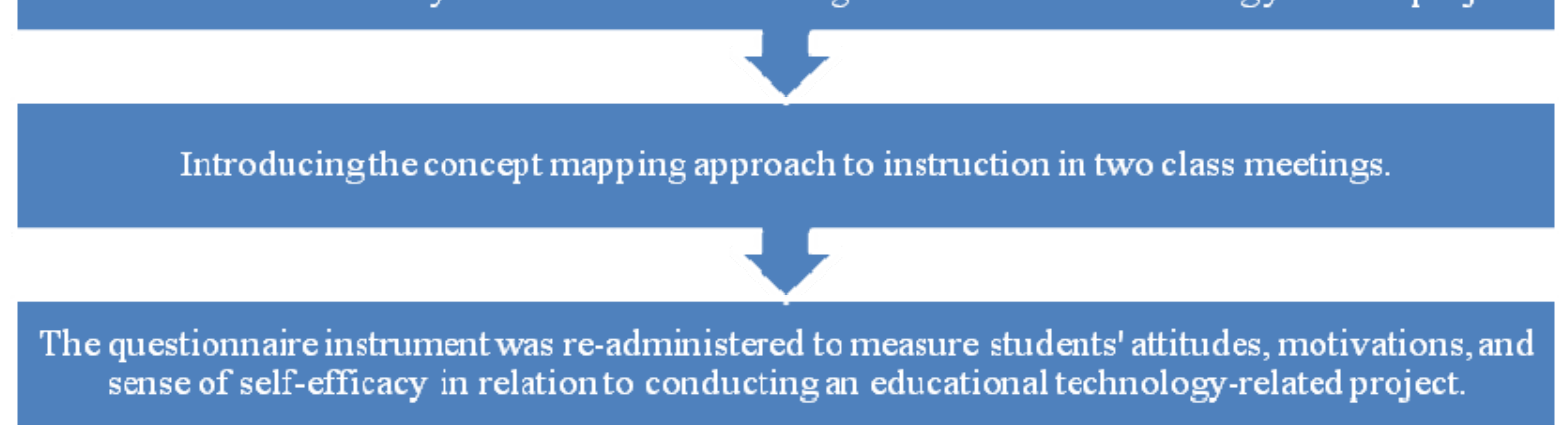

Figure 3. The data collection procedure

The concept mapping approach to instruction was used to teach students how to undertake an educational technology-related project. The concept mapping instruction lasted for two class meetings; each meeting lasted for three hours. Initially, the students learned the construction of concept maps. Then, they learned about the application of concept mapping in conducting and documenting an educational technology-related project in terms of the use of the instructional design model, selecting appropriate types of technologies, and developing a report on the project. Concept mapping used to represent each part and of the project. Figure 4 shows the general concept mapping approach for teaching. 


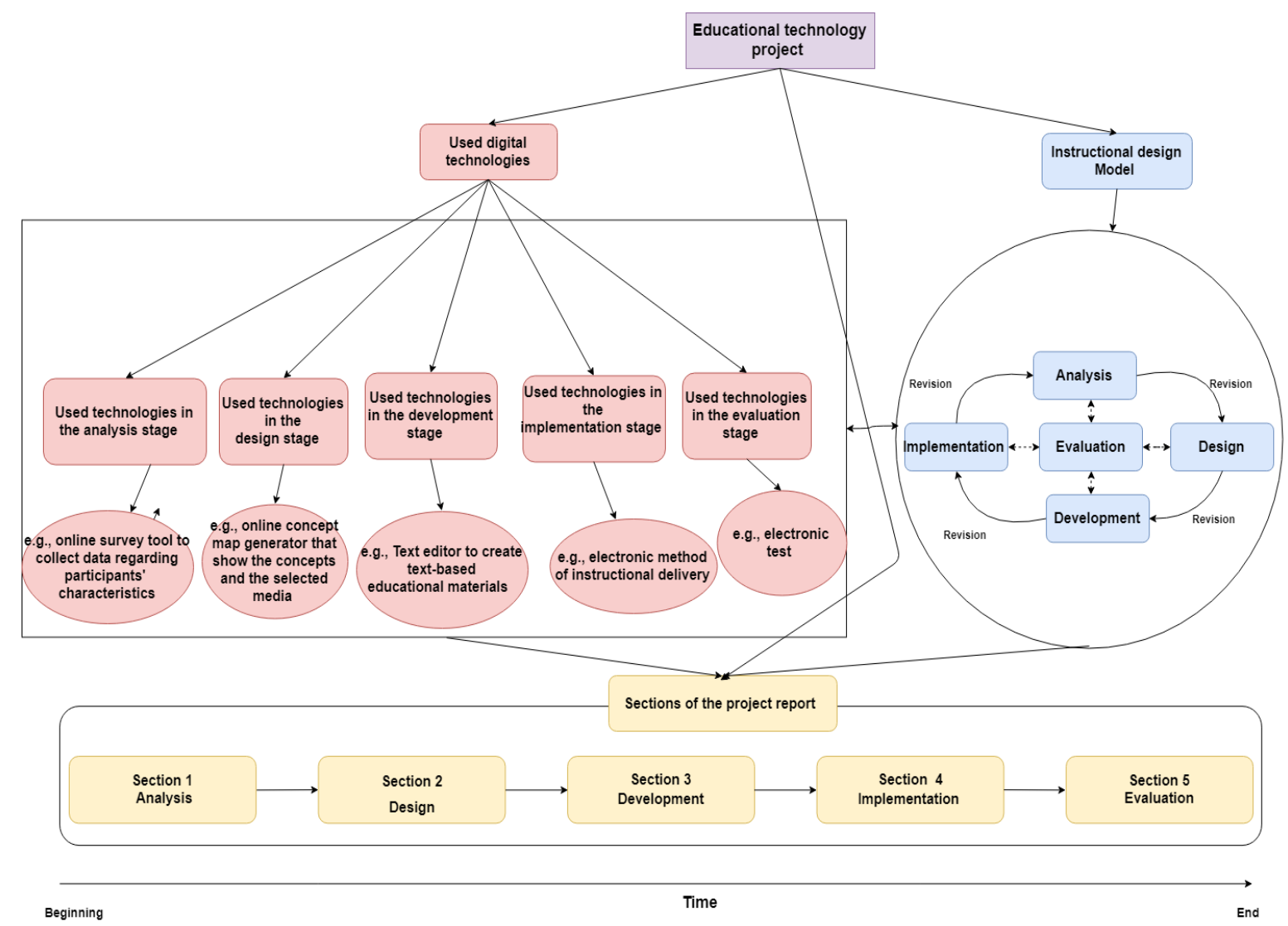

Figure 4. The general concept mapping approach to teaching

\subsection{Data Collection Tool}

Questionnaires were used to collect data. The questionnaire used in the first round of data collection had four parts. The first part collected demographic data about each participant's age, major, academic year, and grade point average (GPA). The second part examined students' attitudes towards conducting an educational technology-related project. The third part examined students' motivation, and the fourth part examined the students' sense of self-efficacy. Only the second, third, and fourth parts were used in the second questionnaire after changing the tenses of the items. Five-point Likert-type scales were used in the second, third, and fourth parts of the questionnaire. The questionnaire questions were developed based on previous research that focused on measuring students' attitudes, motivations, and sense of self-efficacy (e.g., Chiou, 2008; Nobahar et al., 2013; Al-Dmour et al., 2017). The validity of the questionnaire was verified by presenting it to a group of experts. The experts were faculty members at colleges of education in a university in Kuwait. The faculty members reviewed the questionnaire and provided feedback about the clarity and suitability of the questions. To check reliability, Cronbach's Alpha coefficients were computed for data from the two rounds of the study. The values of Cronbach's Alpha were equal to or greater than .8, indicating appropriate internal consistency of the items in the scales. Table 1 shows a summary of the reliability analysis. 


\section{Macrothink}

Table 1. Summary of reliability analysis

\begin{tabular}{llll}
\hline \multirow{2}{*}{ Scale } & Number of scale items & \multicolumn{2}{l}{ Cronbach's Alpha } \\
\cline { 3 - 4 } & & Study, round one $(\mathrm{N}=78)$ & Study, round two (N =78) \\
\hline Attitudes scale & 6 & .83 & .83 \\
Motivation scale & 4 & .82 &. .85 \\
Self-efficacy belief scale & 7 & .80 & .85 \\
\hline
\end{tabular}

\subsection{Participants}

The participants were 78 students enrolled in three sections of a "production of teaching material" course in a college of basic education in a university in Kuwait. In two sections the students were female and in the other the students were male. The total number of students in the three sections was 87 . The response rate was 90 percent. Details on students' demographic characteristics were collected in the first questionnaire. Table 2 shows that about three-quarters of the students $(62.8 \% ; n=49)$ were female, most $(80.8 \% ; n=63)$ were between the ages of 21 and 25 , most $(74.4 \% ; n=58)$ were in their fourth academic year and most $(67.9 \% ; n=53)$ had good GPAs. The participants were majoring in various educational fields. The nature of the class in which the study took place explains the distribution of the students' characteristics. Typically, the class was offered to students in their fourth academic year.

Table 2. Descriptive summary of participants' ages, majors, academic years, and GPAs

\begin{tabular}{llll} 
& Category & Frequency & Per cent \\
\hline Gender & Male & 29 & 37.2 \\
& Female & 49 & 62.8 \\
\hline Age & $18-20$ & 2 & 2.6 \\
& $21-25$ & 63 & 80.8 \\
& $26-30$ & 5 & 6.4 \\
& $31-35$ & 4 & 5.1 \\
& $36-40$ & 1 & 1.3 \\
& More than 40 & 3 & 3.8 \\
\hline Major & Islamic Education & 12 & 15.4 \\
& Science Education & 5 & 6.4 \\
\hline
\end{tabular}


Arabic Language Education

5

10

3

Music Education

Interior Design Education

English Language Education

Electricity Education

Physical Education and Sports

French Language

Math Education

Academic
year

2

3

4

5

GPA

Excellent

Good

Satisfactory

\section{6}

5

5

14

1

4

0

0

8

58

12

5

53

20
6.4

12.8

3.8

7.7

6.4

6.4

17.9

1.3

5.1
0

0

10.3

74.4

15.4
53

20

6.4

67.9

25.6

\subsection{Data Analysis}

Students' responses to the questionnaires were analyzed using SPSS software. The negative items were reversed. Frequency distributions were calculated for participants' demographic data that included their gender, major, academic year, and GPA. Means and standard deviations were computed for each item in the three scales in the questionnaire before and after the use of concept mapping. The paired t-tests for dependent samples were carried out to measure the pre- and post-test scores of the same participants.

\section{Results and Discussion}

In order the examine the effects of the concept mapping instruction on students' attitudes, motivations, and sense of self-efficacy in relation to conducting an educational technology-related project, a paired sample t-test was performed on students' responses to the following three scales: the attitude scale, the motivation scale, and the self-efficacy scale, before and after the delivery of the concept mapping instruction. 


\subsection{Participants' Attitudes}

The results indicate that there were significant changes between students' responses to the overall attitude scale $\left(\mathrm{M}_{\text {pre }}=3.56 ; \mathrm{M}_{\text {post }}=4.22 ; \mathrm{t}(77)=-5.55 ; \mathrm{p}<0.05\right)$ as well as to all the items in the scale (Table 3). The results indicate that the concept mapping approach to teaching improved students' attitudes toward conducting the educational technology-related project. The results are aligned with previous research that showed that a concept mapping approach to teaching enhanced students' attitudes toward conducting projects in the information technology field (Al-Dmour et al., 2017). In addition, the results are aligned with previous research that has shown that a concept mapping approach can enhance students' attitudes toward learning different topics in different fields including circular and rotational motion in physics (Luchembe et al., 2017), and vocabulary acquisition in language learning (Khoshsima et al., 2016).

Table 3. Results of paired t-tests for significant differences of participants' attitudes toward conducting an educational technology-related project

\begin{tabular}{|c|c|c|c|c|c|c|c|}
\hline & \multirow{2}{*}{ Outcome } & \multicolumn{2}{|c|}{ Pre-test } & \multicolumn{2}{|c|}{ Post-test } & \multirow{2}{*}{$\begin{array}{l}\text { 95\% CI for Mean } \\
\text { Difference }\end{array}$} & \multirow[b]{2}{*}{$\mathrm{t}$} \\
\hline & & $M$ & SD & $\mathrm{M}$ & SD & & \\
\hline 1 & The project will be fun. & 3.73 & .75 & 4.18 & .75 & $-.63,-.27$ & $-5.06^{*}$ \\
\hline 2 & I will like doing the project & 3.59 & .76 & 4.08 & .86 & $-.70,-.28$ & $-4.60^{*}$ \\
\hline 3 & $\begin{array}{l}\text { Developing project will be a good idea in } \\
\text { this course. }\end{array}$ & 3.91 & .67 & 4.38 & .71 & $-.64,-.30$ & $-5.58^{*}$ \\
\hline 4 & Developing project will be useful to me. & 4.17 & .65 & 4.38 & .72 & $-.42,-.02$ & $-2.16^{*}$ \\
\hline 5 & $\begin{array}{l}\text { I will develop educational project similar } \\
\text { to this project in the future. }\end{array}$ & 3.87 & .84 & 4.14 & .80 & $-.48,-.06$ & $-2.58^{*}$ \\
\hline \multirow[t]{2}{*}{6} & $\begin{array}{l}\text { I will use the concept mapping approach } \\
\text { to instruction to develop project for my } \\
\text { future students. }\end{array}$ & 3.97 & .85 & 4.46 & .73 & $-.70,-.27$ & $-4.53 *$ \\
\hline & Overall & 3.87 & .56 & 4.27 & .66 & $-.54,-.25$ & $-5.55^{*}$ \\
\hline
\end{tabular}

$* \mathrm{p}<.0, \mathrm{df}=77$.

\subsection{Participants' Motivation}

The results indicate that there were significant changes to students' responses to the overall motivation scale $($ Mpre $=4.04$; Mpost $=4.26 ; \mathrm{t}(77)=-2.91 ; \mathrm{p}<0.05)$ as well as to two items in the scale (Table 4). However, there were no significant changes to students' responses to two of the items in the motivation scale. One of these items was related to sharing their experiences of conducting an educational technology-related project with others, and the other related to their willingness to make an effort to conduct the educational technology-related project. A possible explanation for the absence of a significant impact in these two items is that the 
educational technology-related project was required by the course, and the students were willing to make an effort to complete this project in order to pass the course, and they were expected to share their experiences with each other in order to do so. After the use of the concept mapping approach to teaching, their beliefs were the same before and after their instruction in the concept mapping approach.

The overall results indicate that the concept mapping approach to teaching improved students' motivation for conducting the educational technology-related project. The results aligned with previous studies that showed that the concept mapping approach enhanced students' motivation for learning different topics in different fields including accounting (Chiou, 2008), and biology (Keraro, Wachanga, \& Orora, 2007).

Table 4. Results of paired t-tests for significance differences of participants' motivation in relation to conducting an educational technology-related project

\begin{tabular}{|c|c|c|c|c|c|c|c|}
\hline & \multirow{2}{*}{ Outcome } & \multicolumn{2}{|c|}{ Pre-test } & \multicolumn{2}{|c|}{ Post-test } & \multirow{2}{*}{\multicolumn{2}{|c|}{$\begin{array}{l}95 \% \quad \text { CI for Mean } \\
\text { Difference }\end{array}$}} \\
\hline & & M & SD & M & SD & & \\
\hline 1 & $\begin{array}{l}\text { I will be interested in completing the project } \\
\text { to the end. }\end{array}$ & 4.12 & .68 & 4.36 & .74 & $-.45,-.04$ & $-2.39^{*}$ \\
\hline 2 & I will be excited to complete the project. & 3.81 & .81 & 4.23 & .80 & $-.63,-.22$ & $-4.13^{*}$ \\
\hline 3 & I will share my experiences on the project. & 3.97 & .74 & 4.13 & .80 & $-.36, .05$ & -1.51 \\
\hline 4 & $\begin{array}{l}\text { I will make the required effort to complete the } \\
\text { project. }\end{array}$ & 4.27 & .66 & 4.32 & .71 & $-.23, .13$ & -.57 \\
\hline 5 & Overall & 4.04 & .58 & 4.26 & .64 & $-.37,-.07$ & $-2.91 *$ \\
\hline
\end{tabular}

${ }^{*} p<.05, d f=77$.

\subsection{Participants' Sense of Self Efficacy}

The results indicate that there were significant changes to students' responses to the overall self-efficacy scale $($ Mpre $=3.56$; Mpost $=4.22 ; \mathrm{t}(77)=-10.30 ; \mathrm{p}<0.05)$ as well as to all the items in the scale (Table 5). The results indicate that the concept mapping approach to teaching improved students' sense of self-efficacy in relation to conducting the educational technology-related project. The results align with previous studies that have shown that the concept mapping approach can enhance students' sense of self-efficacy in relation to their achievement and self-regulation in language learning (Chularut \& DeBacker, 2004; Nobahar et al., 2013). 
Table 5. Results of paired t-tests for significance differences of participants' sense of self efficacy belief in relation to conducting an educational technology-related project

\begin{tabular}{|c|c|c|c|c|c|c|c|}
\hline & \multirow[b]{2}{*}{ Outcome } & \multicolumn{2}{|c|}{ Pre-test } & \multicolumn{2}{|c|}{ Post-test } & \multirow{2}{*}{$\begin{array}{l}95 \% \text { CI for Mean } \\
\text { Difference }\end{array}$} & \multirow[b]{2}{*}{$\mathrm{t}$} \\
\hline & & M & SD & M & SD & & \\
\hline 1 & $\begin{array}{l}\text { I will be able to complete the project without } \\
\text { having someone around me telling me what to do. }\end{array}$ & 3.45 & .83 & 4.28 & .85 & $-1.04,-.63$ & $-8.02 *$ \\
\hline 2 & $\begin{array}{l}\text { I am confident that I can complete the project to the } \\
\text { end. }\end{array}$ & 4.03 & .70 & 4.37 & .79 & $-.55,-.14$ & $-3.36^{*}$ \\
\hline 3 & Completing the project will be easy for me. & 3.51 & .68 & 4.37 & .82 & $-1.06,-.66$ & $-8.49 *$ \\
\hline 4 & **The project makes me worry. & 3.32 & .92 & 4.01 & 1.00 & $-.96,-.43$ & $-5.20 *$ \\
\hline 5 & **The project will be confusing. & 3.49 & .91 & 4.21 & .76 & $-.91,-.52$ & $-7.32 *$ \\
\hline 6 & **The project will be complicated. & 3.51 & .86 & 4.21 & .76 & $-.91,-.47$ & $-6.21 *$ \\
\hline & I will be able to develop a high quality project. & 3.64 & .82 & 4.08 & .83 & $-.68,-.20$ & $-3.62 *$ \\
\hline
\end{tabular}

**, Negatively stated item, $* p<.05, d f=77$.

\section{Conclusion}

Tasks requiring students to develop educational technology projects have been included in most educational and educational technology curriculums. These projects are important for evaluating students' learning and for developing their ability to transfer their knowledge and skills in real-world educational environments. Conducting educational technology projects is important for student teachers since these projects provide them with hands-on experience in relation to the best-practice integration of technology in education. The researcher noticed that the student teachers faced many difficulties in designing projects and selecting the appropriate media, as well as in documenting the process of their projects. The current study showed that concept mapping instruction is an effective instructional approach which can enhance university students' attitudes, motivations, and sense of self-efficacy in relation to conducting educational technology-related projects.

\section{References}

Al-Dmour, A., Gasaymeh, A. M., Abuhelaleh, M., \& Almi'ani, M. (2017). Effects of concept map approach on students' attitude and motivation towards documenting computing capstone projects. International Journal of Technology Enhanced Learning, 9(1), 70-79. https://doi.org/10.1504/IJTEL.2017.084069

Al-Nakib, R. (2015). Education and democratic development in Kuwait: Citizens in waiting. Chatham House Research Paper, 7.

Ary, D., Jacobs, L.C., Sorensen,C., \& Razavieh, A. (2010). Introduction to research in 
education (8th ed.). Belmont, CA: Wadsworth.

Bernaus, M., \& Gardner, R. C. (2008). Teacher motivation strategies, student perceptions, student motivation, and English achievement. The Modern Language Journal, 92(3), 387-401. https://doi.org/10.1111/j.1540-4781.2008.00753.x

Busato, V. V., Prins, F. J., Elshout, J. J., \& Hamaker, C. (20000. Intellectual ability, learning style, personality, achievement motivation and academic success of psychology students in higher education. Personality and Individual differences, 29(6), 1057-1068. https://doi.org/10.1016/S0191-8869(99)00253-6

Chen, S. L., Liang, T., Lee, M. L., \& Liao, I. C. (2011). Effects of concept map teaching on students' critical thinking and approach to learning and studying. Journal of Nursing Education, 50(8), 466-469. https://doi.org/10.3928/01484834-20110415-06

Cheung, D. (2015). The combined effects of classroom teaching and learning strategy use on students' chemistry self-efficacy. Research in Science Education, 45(1), 101-116. https://doi.org/10.1007/s11165-014-9415-0

Chiou, C. C. (2008). The effect of concept mapping on students' learning achievements and interests. Innovations in Education and teaching International, 45(4), 375-387. https://doi.org/10.1080/14703290802377240

Chularut, P., \& DeBacker, T. K. (2004). The influence of concept mapping on achievement, self-regulation, and self-efficacy in students of English as a second language. Contemporary Educational Psychology, 29(3), 248-263. https://doi.org/10.1016/j.cedpsych.2003.09.001

Clarke III, I., Flaherty, T. B., \& Yankey, M. (2006). Teaching the visual learner: The use of visual summaries in marketing education. Journal of Marketing Education, 28(3), 218-226. https://doi.org/10.1177/0273475306291466

Keraro, F. N., Wachanga, S. W., \& Orora, W. (2007). Effects of cooperative concept mapping teaching approach on secondary school students' motivation in biology in gucha district, kenya. International Journal of Science and Mathematics Education, 5(1), 111-124.

Khoshsima, H., Saed, A., \& Hakimzade, A. (2016). Effectiveness of concept mapping strategy on EFL learners' Attitude and gender difference outcomes in vocabulary Acquisition. International Journal of Humanities and Cultural Studies (IJHCS), 3(1), 640-656.

Luchembe, D., Chinyama, K., \& Jumbe, J. (2017). The effect of using concept mapping on student's attitude and achievement when learning the physics topic of circular and rotational motion. European Journal of Physics Education, 5(4), 10-29.

McKenzie, K., \& Schweitzer, R. (2001). Who succeeds at university? Factors predicting academic performance in first year Australian university students. Higher education research \& development, 20(1), 21-33. https://doi.org/10.1080/07924360120043621

Mills, H. R. (1991). Teaching and training. A handbook for instructors (3rd ed.). London: Macmillan. 


\section{Macrothink}

International Journal of Learning and Development

ISSN 2164-4063 2019, Vol. 9, No. 2

Nobahar, B., Nemat Tabrizi, A. R., \& Shaghaghi, M. (2013). The Effect of Concept Mapping on Iranian Intermediate EFL Learners' Self-efficacy and Expository Writing Accuracy. Theory \& Practice in Language Studies, 3(11). https://doi.org/10.4304/tpls.3.11.2117-2127

Pintoi, A. J., \& Zeitz, H. J. (1997). Concept mapping: a strategy for promoting meaningful learning in medical education. Medical Teacher, 19(2), 114-121. https://doi.org/10.3109/01421599709019363

\section{Copyright Disclaimer}

Copyright for this article is retained by the author(s), with first publication rights granted to the journal.

This is an open-access article distributed under the terms and conditions of the Creative Commons Attribution license (http://creativecommons.org/licenses/by/4.0/). 